\title{
Relationship between somatotype and physical fitness: study on badminton athletes of PB Djarum Kudus
}

\author{
Nurlita Tri Ayuningtyas ${ }^{1 *}$, Hardhono Susanto ${ }^{2}$, Suroto $^{3}$ \\ ${ }^{1}$ Nutrition Science Postgraduate, Faculty of Medicine, Diponegoro University \\ ${ }^{2}$ Department of Medicine, Faculty of Medicine, Diponegoro University, Indonesia \\ ${ }^{3}$ Department of Public Health, Faculty of Public Health, Diponegoro University, Indonesia \\ * Coressponding Author. E-mail: nurlitatriayuningtyas@gmail.com
}

Received: January 22, 2021; Revised: February 19, 2021; Accepted: April 29, 2021

\begin{abstract}
Badminton athletes should have good physical abilities supported by the suitability of body type (somatotype) as it affects their biomechanics in badminton and performance. The purpose of this study was to explore the correlation between Heath Carter somatotype component factors that affect physical fitness. This study was a cross-sectional research design was used with 43 athletes in PB Djarum Kudus who were selected purposively to be the respondents. The data on Heath Carter somatotype was obtained from anthropometric measurements to generate somatotype scores, namely endomorphy, mesomorphy, and ectomorphy. Cardiorespiratory endurance data were obtained using Balke test, power using vertical jump, and agility using court agility. The somatotype component types of all athletes are central (4.2-4.1-3). Male athletes are of central type (3.5-4-3.5) and females are of mesomorph-endomorph type (5-4-2). Both endomorphy and ectomorphy components showed significant correlation with cardiorespiratory endurance except mesomorphy component. Endomorphy component showed significant correlation with power except for mesomorphy and ectomorphy components. The ectomorphy component with a slender body shape with long arms and legs, low body fat percentage and strong muscle in the arms make it easier for badminton athletes to move in all positions combined.
\end{abstract}

Keywords: somatotype, athlete, badminton, physical fitness

How to Cite: Ayuningtyas, N. T., Susanto, H., \& Suroto, S. (2021). Relationship between somatotype and physical Fitness: study on badminton athletes of PB Djarum Kudus, Jurnal Keolahragaan 9(1), 128-136. https://doi.org/10.21831/jk.v9i1.38147

\section{INTRODUCTION}

Badminton is a sport that requires good physical abilities for its players to do service, smash, lob drop, and footwork to reach the court without significant difficulty (Purnama, 2010). Public demand for the achievements of Indonesian badminton is a serious effort in the process of building achievement through the talent identification and athlete regeneration approach. One of the places to coach badminton athletes is PB Djarum club. This club fosters athletes with special potential for men's and women's singles who are given scholarships for talented young athletes and are given dormitories for living and training. For better achievement, badminton athletes should have high technical and mental abilities, as well as physical abilities, especially speed, agility, aerobic capacity, strength, and body composition that affect their performance and athlete's appearance. (Diputra, 2015; Jeyaraman et al., 2012; Weatherwax, 2011)

The difference characteristics in each sport cause the need for a balance or fit of body type because in various sports there will be different physical and physiological characteristics. The characteristics of an athlete's body are determined by assessing his body type (somatotype) as a quantification of body composition and body shape which is important in athlete selection because it will affect the biomechanics of a sport (Duncan et al., 2006; Gutnik et al., 2015). The superiority of somatotype assessment to determine athlete's body shape in various sports has a positive correlation with height which significantly affects physical fitness (Carter, 2005; Malousaris et al., 2008). The principle of motion during sports activities requires mechanical performance and appropriate posture so that every movement that is carried out plays a role in terms of energy efficiency and saves energy so that athletes 
do not tire easily (Massidda, 2013). Considering biomechanics, long legs, wrist flexibility, and arm length gain advantages in terms of the lever so that athletes exert a large amount of force on the ability to do drop shot in badminton, affecting their sports achievements (Komari, 2010; Rizal, 2012).

The somatotype component of the Heath Carter method in each sport is found to be not homogeneous. In athletics, gymnastics, and volleyball, the players tend to have a more mesomorphy somatotype compared to judo and hockey players who have a more endomesomorphy somatotype. Badminton players with an average height and leanness meet the characteristic of having an ectomesomorphic body according to the physiological demands of competition (Raković et al., 2015; Lieshout, 2003; Singh, 2011)

The importance of identifying characteristics that contribute to the ability to play badminton will affect improving the performance of badminton players. A part from being an important part of the evaluation in various sports, standard data of physical parameters, anthropometric measurements, body composition, and athlete's somatotype are still lacking in Indonesia, especially in badminton. Besides, somatotype identification was found to achievement in tennis players, so it is expected that somatotype identification will be the basis for the selection of badminton athletes and other sports in Indonesia. (Rahmawati, 1996; Saputri, 2011). Therefore, this study explores the relationship between Heath Carter's somatotype component factors and the physical fitness of badminton athletes at PB Djarum Kudus, a badminton club in Kudus.

\section{METHOD}

This study was an observational study with a cross-sectional design. It was conducted from January to March 2020 at PB Djarum Kudus. A total of 43 badminton athletes (23 males and 20 females) were selected to be the subjects of this study using purposive sampling. The inclusion criteria of subjects were athletes aged 13-19 years, willing to be a research sample by filling out the informed consent from the beginning to the end of study, physically healthy and not recovering from injuries, have participated in provincial level competitions, able to communicate well and not suffering from illnesses and health conditions that contradict with a physical test. The dependent variable in this study is physical fitness and the independent variable is somatotype, while the confounding variables include age, gender, hemoglobin level, duration of the training, body fat percentage, muscle mass percentage, and nutritional status.

Anthropometric measurements include height, weight, skinfold (triceps, suprailiac, subscapular, and calf skinfold), body circumference (calf girth and biceps girth), and bone width (femur width and humerus width). Height was measured using a microtoa with a scale of up to $1 \mathrm{~mm}$. Bodyweight, body fat percentage, and muscle mass percentage were measured using Omron Karada HBF-375 BIA scale. Skinfold data were obtained using the skinfold caliper. Body circumference was measured using anthropometric tape. Bone width is measured using a caliper. These components are needed in determining the somatotype. After they were measured, the results were entered into the formula according to the Heath Carter method to obtain the endomorphy, mesomorphy, and ectomorphy scores, respectively (Carter, 2002). The physical fitness test includes cardiorespiratory endurance, power, and agility. Cardiorespiratory endurance was tested by measuring the cardiorespiratory rate (VO2max) obtained by Balke test. Power was tested by measuring the number of achievements obtained by vertical jump. Agility was tested by measuring the total seconds obtained by court agility.

SPSS 16.0 was used for statistical data analysis. Univariate analysis was used to describe the characteristics of the research subjects while bivariate analysis was used to see the relationship between the independent (somatotype), moderating (age, sex, hemoglobin level, training status, body fat percentage, muscle mass percentage, and nutritional status), and dependent variables (physical fitness). Kolmogorov-Smirnov test $(\mathrm{p}<0.05)$ was used to test data distribution normality. To test normally distributed relationships, Pearson correlation test was performed. Spearman Rank correlation test was performed to test the relationship of independent variables that are not normally distributed. Multiple linear regression test was used for multivariate analysis between confounding variables and Heath Carter's somatotype with physical fitness. 
Jurnal Keolahragaan 9 (1), 2021 - 130

Nurlita Tri Ayuningtyas, Hardhono Susanto, Suroto Suroto

\section{RESULT AND DISCUSSION}

Total 43 athletes from PB Djarum Kudus were the subjects in this study with an average age of 14 years with an average maturation of 10 years. Data on subject characteristics consisted of age, maturation, hemoglobin level, duration of the training, nutritional status, body fat percentage, muscle mass percentage, VO2max, vertical jump, and court agility. Badminton athletes had a mean hemoglobin level of $12.6 \%$, length of training of 7 years, body fat of $18.74 \pm 5.74 \%$; the percentage for females of $24.30 \pm 2.33 \%$ greater than for males of $13.90 \pm 2.37 \%$, muscle mass of $33.51 \pm 4.95 \%$; the percentage for males is $37.84 \pm 1.55 \%$ greater than for females of $28.53 \pm 1.61 \%$, nutritional status of $0.023 \mathrm{SD}$. According to the nutritional status classification, (Kemenkes RI, 2010) 41 (95,3\%) of the athletes were classified as normal weight. The mean of $\mathrm{VO} 2$ max was $45.91 \pm 3.78 \mathrm{ml} / \mathrm{minute} / \mathrm{kgBW}$ with the most dominant category of very good by $60.5 \%$, vertical jump is $50.12 \pm 7.1 \mathrm{~cm}$ with the most dominant category of good by $53.5 \%$ and court agility is $10.32 \pm 1.0$ secs with the most dominant category of very good by $53.5 \%$.

Table 1. Subject Characteristics

\begin{tabular}{|c|c|c|c|}
\hline Characteristics & $\mathbf{N}$ & $\%$ & Mean \pm SD \\
\hline \multicolumn{4}{|l|}{ Age (years) } \\
\hline Male & 23 & 53.5 & $14.78 \pm 1.53$ \\
\hline Female & 20 & 46.5 & $15.05 \pm 1.82$ \\
\hline Maturation (year) & & & $10.33 \pm 5.45$ \\
\hline Hemoglobin Level (\%) & & & $12.6 \pm 1.77$ \\
\hline Duration of Training (year) & & & $7.94 \pm 1.91$ \\
\hline Nutritional Status (zscore) & & & $0.02 \pm 0.61$ \\
\hline Underweight & 1 & 2.30 & \\
\hline Normal & 41 & 95.30 & \\
\hline Overweight & 1 & 2.30 & \\
\hline Body Fat Percentage (\%) & & & $18.74 \pm 5.74$ \\
\hline Male & & & $13.90 \pm 2.37$ \\
\hline Female & & & $24.30 \pm 2.33$ \\
\hline Muscle Mass Percentage (\%) & & & $33.51 \pm 4.95$ \\
\hline Male & & & $37.84 \pm 1.55$ \\
\hline Female & & & $28.53 \pm 1.61$ \\
\hline $\mathrm{VO}_{2 \max }(\mathrm{ml} / \mathrm{min} / \mathrm{kgBW})$ & & & $45.91 \pm 3.78$ \\
\hline Very good & 26 & 60.50 & \\
\hline Good & 14 & 32.60 & \\
\hline Enough & 3 & 7 & \\
\hline Vertical Jump (cm) & & & $50.12 \pm 7.10$ \\
\hline Very good & 8 & 18.60 & \\
\hline Good & 23 & 53.50 & \\
\hline Enough & 12 & 27.90 & \\
\hline Court Agility (second) & & & $10.32 \pm 1.03$ \\
\hline Very good & 23 & 53.50 & \\
\hline Good & 13 & 30.20 & \\
\hline Enough & 4 & 9.30 & \\
\hline Poor & 3 & 7 & \\
\hline
\end{tabular}

The mean height of male athletes is $166 \mathrm{~cm}$ with a bodyweight of $54.7 \mathrm{~kg}$ while the average height of the females is $160 \mathrm{~cm}$ with a bodyweight of $54 \mathrm{~kg}$. All skinfold categorical variables are higher in females than males. Male athletes were significantly lower values for calf $(11.43 \pm 2.42 \mathrm{vs} 13.40 \pm 3.08$ $\mathrm{mm})$, triceps $(11.74 \pm 2.78$ vs $15.90 \pm 3.12 \mathrm{~mm})$, suprailiac $(12.78 \pm 5.08$ vs $17.32 \pm 2.91 \mathrm{~mm})$, and subscapula ( $11.54 \pm 3.31$ vs $15.35 \pm 2.99 \mathrm{~mm}$ ). These results were similar to previous studies on Spanish badminton athletes, which showed that female athletes have more triceps and subscapula than male athletes.[12] For the width category (humerus and femur), it was found to be higher in males than females $(6,22 \pm 0,76$ vs $5,91 \pm 0,53 \mathrm{~cm}$ and $7,79 \pm 1,35 \mathrm{vs} 7,10 \pm 0,66 \mathrm{~cm})$. The average bicep girth and calf girth are different between males and females; the average bicep girth is higher in females $(25,17 \pm 2,33$ vs $25,26 \pm 1,99 \mathrm{~cm})$ while calf girth is higher in males $(35,93 \pm 3,90$ vs $35,37 \pm 2,81 \mathrm{~cm})$. The mean somatotype for badminton athletes was: 4.2-4.1-3. This suggests that these athletes were predominantly 
central according to Carter and Heath's classification. This is following several studies on badminton athletes stating all component values are in the middle of the somatochart and are included in the central category (Phomsoupha M, 2015). The mean of endomorphy component for males is lower than that of females, which is 3.5. The mean of mesomorphy component in both genders is the same, which is 4 , and the mean of ectomorphy component of males is higher than that of females, which is 3.5 . The male respondents have an average somatotype (3.5-4-3.5) included in the central type. The average somatotype of female athletes is 5-4-2 included in mesomorph-endomorph type based on plotting on somatochart.

Table 2. Anthropometric Characteristics

\begin{tabular}{|c|c|c|c|c|c|c|}
\hline \multirow{2}{*}{ Variable } & \multicolumn{3}{|c|}{ Male } & \multicolumn{3}{|c|}{ Female } \\
\hline & Mean \pm SD & Min & Max & Mean \pm SD & Min & Max \\
\hline Body height (cm) & $166.10 \pm 6.96$ & 156 & 180.5 & $160.1 \pm 5.32$ & 152 & 170 \\
\hline Body weight (kg) & $54.77 \pm 8.55$ & 41.3 & 71.10 & $54.04 \pm 6.15$ & 38.60 & 66.50 \\
\hline Calf skinfold (mm) & $11.43 \pm 2.42$ & 7 & 16 & $13.40 \pm 3.08$ & 9.50 & 21 \\
\hline Triceps skinfold (mm) & $11.74 \pm 2.78$ & 7 & 18 & $15.90 \pm 3.12$ & 11 & 23 \\
\hline Suprailiac skinfold (mm) & $12.78 \pm 5.08$ & 5 & 25 & $17.32 \pm 2.91$ & 11 & 22 \\
\hline Subscapula skinfold (mm) & $11.54 \pm 3.31$ & 6 & 19 & $15.35 \pm 2.99$ & 9 & 20 \\
\hline Bicep girth $(\mathbf{c m})$ & $25.17 \pm 2.33$ & 21 & 29 & $25.26 \pm 1.99$ & 20 & 29 \\
\hline Calf girth (cm) & $35.93 \pm 3.90$ & 31.50 & 50.40 & $35.37 \pm 2.81$ & 26 & 39.50 \\
\hline Humerus width (cm) & $6.22 \pm 0.76$ & 5 & 7.81 & $5.91 \pm 0.53$ & 3.81 & 6.38 \\
\hline Femur width (cm) & $7.79 \pm 1.35$ & 3.25 & 9.78 & $7.10 \pm 0.66$ & 4.69 & 8.09 \\
\hline \multicolumn{7}{|l|}{ Somatotype } \\
\hline Endomorphy & $3.5 \pm 0.87$ & 2.5 & 6.0 & $5.07 \pm 0.76$ & 3.0 & 6.0 \\
\hline Mesomorphy & $3.5 \pm 0.87$ & 2.5 & 6.0 & $4.25 \pm 0.50$ & 3.0 & 5.0 \\
\hline Ectomorphy & $3.56 \pm 1.00$ & 1.0 & 5.0 & $2.47 \pm 0.73$ & 1.0 & 4.0 \\
\hline
\end{tabular}

Table 3 shows the correlation between somatotype components and physical fitness characteristics of badminton athletes. There was a significant negative correlation between endomorphy component and cardiorespiratory endurance $(\mathrm{r}=-0.666, \mathrm{p}=<0.000)$. Endomorph, has lots of body fat as a negative impact due to the amount of body fat giving an unfavorable burden on heart function during exercise as a result of body muscles failing to take in sufficient amounts of oxygen due to deposition of high amounts of fat mass (de Faria et al., 2016; Moss et al., 2015). A significant negative relationship between aerobic capacity and increased fat tissue was mentioned in a study of badminton athletes before (Aini et al., 2019). Athlete's body mass affects the athlete's movement which causes a decrease in the chance of aerobic capacity value due to an increase in temperature that causes fatigue in the athletes (Brezdeniuk, 2014; Ortega et al., 2013). A significant positive correlation between ectomorphy component and cardiorespiratory endurance $(\mathrm{r}=0.455, \mathrm{p}=<0.013)$ due to the negative effect of body weight causes an ectomorph component (long, lean and low body fat percentage) has advantages over other components (Jakšić D, 2009). A high level of aerobic capacity is indispensable for achieving success in many sports, especially badminton players who involve movement and strength in a relatively small area (Faude et al., 2007; Sharkey, 2013). Another study also explained that the greatest gain in aerobic capacity is dominated by the ectomorphy component (Chaouaci, 2005). Meanwhile, there is no significant correlation between mesomorphy component and cardiorespiratory endurance $(r=-0,146$, $\mathrm{p}=0.351)$. These results differ from previous studies which showed that the muscle strength of the high mesomorphy component can affect a healthier cardiorespiratory endurance profile (Ortega et al., 2013). The mesomorphy component, which refers to the development of musculoskeletal muscles, is a major predictor of muscle strength which has a relationship with the VO2max value (Saiti et al., 2014). However, most of the badminton athletes in previous studies had ectomesomorphy and endoectomorphy components (Saputri, 2011; Raman, 2013). 
Jurnal Keolahragaan 9 (1), 2021 - 132

Nurlita Tri Ayuningtyas, Hardhono Susanto, Suroto Suroto

Table 3. The Relationship between Somatotype and Physical Fitness

\begin{tabular}{lcccccc}
\hline \multirow{2}{*}{ Variable } & \multicolumn{2}{c}{ VO2max } & \multicolumn{2}{c}{ Vertical jump } & \multicolumn{2}{c}{ Court agility } \\
\cline { 2 - 7 } & $\mathbf{r}$ & $\boldsymbol{P}$ & $\mathbf{R}$ & $\boldsymbol{p}$ & $\mathbf{r}$ & $\boldsymbol{P}$ \\
\hline Endomorphy & -0.666 & $<0.000^{* *}$ & -0.462 & $<0.002^{* *}$ & 0.290 & $0.059^{* *}$ \\
Mesomorphy & -0.146 & $0.351^{* *}$ & -0.103 & $0.513^{* *}$ & -0.008 & $0.957^{* *}$ \\
Ectomorphy & 0.455 & $<0.002^{*}$ & 0.280 & $0.069^{*}$ & -0.094 & $0.550^{*}$ \\
\hline
\end{tabular}

*Pearson test

**Spearman Rank test

There was a significant negative correlation between endomorphy component and power ( $\mathrm{r}=-$ $0,462, \mathrm{p}=<0.002$ ). A previous study also showed the same results that the endomorphy component as an indicator of obesity in athletes has a negative effect where high jumping performance becomes difficult to do, which is negatively influenced by high body fat values. Other study states that athletes with lower percent body fat demonstrated the highest vertical jump performance mass (de Faria et al., 2016; Moss et al.,2015; Davis et al., 2003). In general, female athletes have a higher percentage of body fat, especially in the hips and chest than male athletes, so that male athletes will have an advantage in the vertical jump (Dizon, 2012). There was no significant correlation between mesomorphy component and power $(\mathrm{r}=-$ $0.103, \mathrm{p}=0.513$ ). A previous study showed that volleyball players have a somatotype predominantly mesomorphy which means muscular body type, thus contributing to their jumping ability. However, if the athlete has muscles that too big and thick could also interfere with movement, especially in badminton which demands power in the game. It has been shown from this study that there is a low negative correlation between mesomoprhy component and power (Aslan, 2011; Sánchez-Muñoz et al., 2020; Courel-Ibáñez, 2019). There was no significant correlation between ectomorphy component and power $(\mathrm{r}=0,280, \mathrm{p}=0.069)$ supported by a previous study on volleyball that requires jumping because the ectomorphy component has a lower correlation for strength test results (Buśko K, 2013). Ectomorphy which refers to the linearity of height and weight is not an unfavorable factor for shorter athletes because technical factors are also used to increase the effect of jumping. However, in the study of badminton players who were tall and slender were found to match with the characteristics of badminton matches resulting in a variety of strokes (Angga, 2019).

There was no significant correlation between endomorphy component and agility $(r=0.290$, $\mathrm{p}=0.059$ ). This is different from a previous study on badminton athletes in the Philippines, explaining the relationship of the amount of fat as a component of endomorphy as seen from the positive correlation result; it means that higher endomorphy values require a longer time of the athlete's court agility (Kim, 2013; Reilly, 2005). In the game of badminton, the foot functions as a support for the body to move in all directions quickly, influenced by the muscle strength that increases with age. A study on children in badminton group aged 8-10 years stated that effective footwork exercises can affect the agility of badminton games (Van 2002 \& Yüksel 2019)

There is no significant correlation between mesomorphy component and agility ( $\mathrm{r}=-0.008$, $\mathrm{p}=0.957)$. This is contrary to a previous study showing that the mesomorphy component with muscle maturity is associated with agility in adolescent athletes. Muscle mass, which is an indicator of sports performance, contributes to energy production during highly intensive activities and provides absolute strength to the athlete (Myburgh, 2016; Vila, 2008). However, previous study showed results that a badminton athlete with a long and lean body is suitable for the physiological demands of the competition (Singh, 2019). There is no significant relationship between ectomorphy and agility $(r=0.094, p=0.550)$ supported by a previous study which explains that relative height and weight and more muscle mass can result in very strong punches and agility in changing positions quickly of racket players (SánchezMuñoz, 2020). The ectomorphy type as a tall and thin body type is known to greatly influence the success of the game rally when the player hits the ball high above the head, such as in tennis and padel games. A thin body, low body weight and long legs are considered more useful for reaching the court during badminton games (Angga, 2019; Courel-Ibáñez, 2019).

The results of the regression analysis conducted to test the intensity of influence of confounding variables and somatotype on physical fitness are presents in Table 4 . This finding indicates that $62,8 \%$ of the scores of the "cardiorespiratory endurance" variable can be explained by age, nutritional status, muscle mass percentage, and ectomorphy. The body's energy system during badminton requires sufficient aerobic capacity for play and recovery. In the younger group of badminton athletes, VO2max 
values were higher even though they still lacked experience in playing (Heller, 2010). The ectomorphy component has a significant advantage in the aerobic capacity of an individual because the excess fat composition causes faster fatigue so that athletes with a higher percentage of muscle mass will produce high VO2max values (Chaouachi, 2005; Cinarli, 2019).

Table 4. Linier Regretion Analysis of Confounding Variable and Somatotype Heath Carter

\begin{tabular}{lccc}
\hline \multicolumn{1}{c}{ Variabel } & $\mathrm{P}$ & $\mathrm{r}$ & $\mathrm{R}^{2}$ \\
\hline Cardiorespiratory endurance* & & & \\
Age & 0.028 & & \\
Nutritional Status & 0.010 & 0.792 & 0.628 \\
Muscle Mass (\%) & 0.000 & & \\
$\quad$ Ectomorphy & 0.008 & & \\
Power* & & & \\
$\quad$ Body Fat (\%) & 0.000 & 0.683 & \\
Ectomorphy & 0.024 & & \\
Agility* & 0.010 & & \\
Age & 0.010 & 0.646 \\
Hb Level & 0.001 & 0.803 & \\
Body Fat (\%) & 0.087 & & \\
Endomorphy & & &
\end{tabular}

This finding indicates that $46,6 \%$ of the scores of the "power" variable can be explained by body fat percentage and ectomorphy. The ectomorphy component with a low body mass index value correlates significantly with the maximum strength value measured by jumping motion because a high percentage of body fat will make it difficult for body movement when jumping from various postures. (Hong et al., 2014; Reiser et al., 2006). Ideal height and weight with good physical condition will support the athlete's high sports performance. A study of badminton players in Malaysia with a lower body fat percentage and higher height would give athletes an advantage in the game of badminton as it contributes to the ability to reach the court. However, this is only one of several factors that influence success in badminton. (Ooi, 2009)

This finding indicates that $64,6 \%$ of the scores of the "agility" variable can be explained by age, hemoglobin level, body fat percentage, and endomorphy. Badminton is a racquet sport that demands moving agility during the game requires an oxygen supply which is influenced by hemoglobin levels as oxygen transport into the blood. During the game rally, athletes who have a smaller body fat percentage make it easier for athletes to change positions due to fat accumulation which causes muscle imbalance due to friction of fat tissue in the muscle fibers, so that muscle contraction will be reduced. (Tiwari, 2011; Kim, 2013)

The contribution of morphological factors such as somatotype to sports performance also affects the functional response at the peak performance of athletes (Bolonchuk, 2000). Badminton athletes and their coaches are positively able to understand the importance of the Heath Charter somatotype to boost athlete achievements. Athletes with good endomorphy components and high mesomorphy and ectomorphy components but without maximal intensive training will have less optimal performance (Andersen, 2007; Tangkudung, 2006). This study is limited by the total results of PB Djarum athletes who tend to have endomorphy and central somatotype types. This can be due to data collection carried out after the athletes had Christmas and New Year holidays at their homes, making their diet and training patterns not maximally controlled.

\section{CONCLUSION}

In conclusion, the findings of this study indicate that there is a significant correlation between endomorphy and ectomorphy components with cardiorespiratory endurance, and endomorphy components with power. On the other hand, there is no significant correlation between endomorphy, mesomorphy, and ectomorphy components with agility. The advantages of the ectomorphy component with a slender body shape with long arms and legs, low body fat percentage and strong muscle in the arms make it easier for badminton athletes to move in all positions combined. 


\section{Jurnal Keolahragaan 9 (1), 2021 - 134}

Nurlita Tri Ayuningtyas, Hardhono Susanto, Suroto Suroto

\section{REFERENCES}

Aini, T. R. N., Rahfiludin, M. Z., \& Kartini, A. (2019). Hubungan persen lemak tubuh dan kadar hemoglobin dengan kapasitas VO2max atlet bulut angkis: Studi di UKM Bulutangkis Universitas Negeri Semarang dan Universitas Diponegoro. Media Kesehatan Masyarakat Indonesia, 18(4), 1-4.

Angga, P. D. (2019). Anthropometric and motor performance of junior badminton athlete. Atlantis Press, 7, 143-146.

Andersen, L. L., Larsson, B., Overgaard, H., \& Aagaard, P. (2007). Torque-velocity characteristics and contractile rate of force development in elite badminton players. European Journal of Sport Science, 7(3), 127-134.

Aslan, C. S., Koc, H., Aslan, M., \& Ozer, U. (2011). The effect of height on the anaerobic power of sub-elite athletes. World Applied Science Journal, 12(2), 208-211.

Bolonchuk, W. W., Siders, W. A., Lykken, G. I., \& Lukaski, H. C. (2000). Association of dominant somatotype of men with body structure, function during exercise, and nutritional assessment. American Journal of Human Biology: The Official Journal of the Human Biology Association, 12(2), 167-180.

Brezdeniuk, O. (2014). Aerobic possibilities of 17-21 year students with different components of body mass. Fizichna aktivnist', zdorov'ia i sport, 1, 9-18.

Buśko, K., Lewandowska, J., Lipińska, M., Michalski, R., \& Pastuszak, A. (2013). Somatotypevariables related to muscle torque and power output in female volleyball players. Acta of Bioengineering and Biomechanics, 15(2), 119-126.

Carter, J. E. L. (2002). Part 1: The Heath-Carter anthropometric somatotype-instruction manual. Department of Exercise and Nutritional Sciences San Diego State University.

Chaouachi, M., Chaouachi, A., Chamari, K., Chtara, M., Feki, Y., Amri

, M., \& Trudeau, F. (2005). Effects of dominant somatotype on aerobic capacity trainability. British journal of sports medicine, 39(12), 954-959.

Çinarli, F. S., \& Kafkas, M. E. (2019). The effect of somatotype characters on selected physical performance parameters. Physical education of students, 23(6), 279-287.

Courel-Ibáñez, J., Martinez, B. J. S. A., \& Marín, D. M. (2019). Exploring game dynamics in padel: implications for assessment and training. The Journal of Strength \& Conditioning Research, 33(7), 1971-1977.

Davis, D. S., Briscoe, D. A., Markowski, C. T., Saville, S. E., \& Taylor, C. J. (2003). Physical characteristics that predict vertical jump performance in recreational male athletes. Physical therapy in Sport, 4(4), 167-174.

de Faria Pastore, J. C., de Azevedo Ferreira, C. A., da Costa, F. C. H., \& João, P. V. (2016). Kinanthropometric profile of beach volleyball player of category under 19 and under 21 of European championship. Chest, 80(2.3), 83-9.

Diputra, R. (2015). pengaruh latihan three cone drill, four cone drill, dan five cone drill terhadap kelincahan (agility) dan kecepatan (speed). Jurnal SPORTIF: Jurnal Penelitian Pembelajaran, 1(1), 41-59.

Dizon, J., \& Grimmer-Somers, K. (2010). Making Filipino taekwondo athletes internationally competitive: An international comparison of anthropometric and physiologic characteristics. Journal of Science and Medicine in Sport, 12, e131-e132.

Duncan, M. J., Woodfield, L., \& Al-Nakeeb, Y. (2006). Anthropometric and physiological characteristics of junior elite volleyball players. British Journal of Sports Medicine, 40(7), 649651.

Faude, O., Meyer, T., Rosenberger, F., Fries, M., Huber, G., \& Kindermann, W. (2007). Physiological characteristics of badminton match play. European journal of applied physiology, 100(4), 479485 . 
Gutnik, B., Zuoza, A., Zuozienè, I., Alekrinskis, A., Nash, D., \& Scherbina, S. (2015). Body physique and dominant somatotype in elite and low-profile athletes with different specializations. Medicina, 51(4), 247-252.

Heller, J. (2010). Physiological profiles of elite badminton players aspects of age and gender. $\mathrm{Br} J$ Sports Med, 44(Suppl I), 17.

Hong, Y., Wang, S. J., Lam, W. K., \& Cheung, J. T. M. (2014). Kinetics of badminton lunges in four directions. Journal of applied biomechanics, 30(1), 113-118.

Jakšić, D., \& Cvetković, M. (2009). Neural network analysis of somatotype differences among males related to the manifestation of motor abilities. Acta Kinesiologica, 3(1), 107-113.

Jeyaraman, R., District, E., \& Nadu, T. (2012). Prediction of playing ability in badminton from selected anthropometrical physical and physiological characteristics among inter collegiate players. Int J Adv Innov Res, 2(3), 11.

Kim, M., Cruz, A., \& Kim, H. (2013). Anthropometric profiles of Filipino badminton collegiate players. Asia Life Sci, 22(2), 1-6.

Komari, A. (2010). Biomekanika olahraga. Yogyakarta: FIK UNY.

Lieshout, K. A., \& Lombard, A. J. (2003). Fitness profile of elite junior South African badminton players. African Journal for Physical Activity and Health Sciences, 9(3), 114-120.

Massidda, M., Toselli, S., Brasili, P., \& M Calo, C. (2013). Somatotype of elite Italian gymnasts. Collegium antropologicum, 37(3), 853-857.

Malousaris, G. G., Bergeles, N. K., Barzouka, K. G., Bayios, I. A., Nassis, G. P., \& Koskolou, M. D. (2008). Somatotype, size and body composition of competitive female volleyball players. Journal of science and medicine in sport, 11(3), 337-344.

Moss, S. L., McWhannell, N., Michalsik, L. B., \& Twist, C. (2015). Anthropometric and physical performance characteristics of top-elite, elite and non-elite youth female team handball players. Journal of Sports Sciences, 33(17), 1780-1789.

Myburgh, G. K., Cumming, S. P., Silva, M. C. E., Cooke, K., \& Malina, R. M. (2016). Maturityassociated variation in functional characteristics of elite youth tennis players. Pediatric exercise science, 28(4), 542-552.

Ooi, C. H., Tan, A., Ahmad, A., Kwong, K. W., Sompong, R., Mohd Ghazali, K. A., \& Thompson, M. W. (2009). Physiological characteristics of elite and sub-elite badminton players. Journal of sports sciences, 27(14), 1591-1599.

Ortega, F. B., Ruiz, J. R., \& Castillo, M. J. (2013). Physical activity, physical fitness, and overweight in children and adolescents: evidence from epidemiologic studies. Endocrinología y Nutrición (English Edition), 60(8), 458-469.

Phomsoupha, M., \& Laffaye, G. (2015). The science of badminton: game characteristics, anthropometry, physiology, visual fitness and biomechanics. Sports medicine, 45(4), 473-495.

Purnama, S. K. (2010). Kepelatihan bulutangkis modern. Surakarta: Yuma Pustaka.

Raman, D., \& Nageswaran, A. (2013). Effect of game-specific strength training on selected physiological variables among badminton players. SSB, 1(57.563), 57-563.

Rahmawati, N. T. R. N. T. (1996). Beberapa ukuran antropometri pada atlet sepakbola dan bulutangkis di Yogyakarta. Journal of the Medical Sciences (Berkala ilmu Kedokteran), 28(02).

Raković, A., Savanović, V., Stanković, D., Pavlović, R., Simeonov, A., \& Petković, E. (2015). Analysis of the elite athletes' somatotypes. Acta Kinesiologica, 9(1), 47-53.

Reiser II, R. F., Rocheford, E. C., \& Armstrong, C. J. (2006). Building a better understanding of basic mechanical principles through analysis of the vertical jump. Strength and Conditioning Journal, 28(4), 70.

Rizal, A. (2012). Kontribusi panjang lengan, kelentukan pergelangan tangan terhadap kemampuan pukulan dropshot bulutangkis mahasiswa FIK UNM Makassar. Jurnal Pendidikan Jasmani Kesehatan Dan Rekreasi FIK UNM, 3(3), 26-38. 
Jurnal Keolahragaan 9 (1), 2021 - 136

Nurlita Tri Ayuningtyas, Hardhono Susanto, Suroto Suroto

Saiti, B., Shukova-Stojmenovska, D., Zhivkoviq, V., Dalip, M., Ganiu, V., Telai, B., \& Ademi, A. (2014). Correlation between components of the somatotype and motor skills of young soccer participant in the first league in Republic of Macedonia. Proceedings (2014): Sport and Health, 1(1), 18-25.

Sánchez-Muñoz, C., Muros, J. J., Cañas, J., Courel-Ibáñez, J., Sánchez-Alcaraz, B. J., \& Zabala, M. (2020). Anthropometric and physical fitness profiles of world-class male padel players. International Journal of Environmental Research and Public Health, 17(2), 508.

Saputri, OA. (2011). Hubungan somatotype heath- carter dengan pencapaian prestasi pada atlet tenis P.R Sukun Kudus tahun 2011. Under Graduates thesis, Universitas Negeri Semarang.

Sharkey, B. J., \& Gaskill, S. E. (2013). Fitness \& health. Human Kinetics.

Singh, B. B., \& Singh, J. (2011). A comparative study on somatotypes of north zone badminton and tennis players. Variorum Multidiscip eRes J, 2(1), 1-8.

Tangkudung, J. (2006). Profil tinggi badan, berat badan dan indeks massa tubuh (IMT) atlet Piala Thomas dan Uber. Jurnal Iptek Olahraga, 8(3), 192-205.

Tiwari, L. M., Rai, V., \& Srinet, S. (2011). Relationship of selected motor fitness components with the performance of badminton player. Asian J Phys Educ Comput Sci Sports, 5(1), 88-91.

Vila Suarez, M.H., Ferragut, C., Alcaraz, P.E., Rodriguez Suarez, N. \& Cruz Martinez, M. (2008). Anthropometric and strength characteristics in young handball players by playing positions. $J$. Arch. Sport Med.,25(125), 167-77.

Van Praagh, E., \& Doré, E. (2002). Short-term muscle power during growth and maturation. Sports medicine, 32(11), 701-728.

Weatherwax-Fall, D., \& LD, A. (2011). Body composition and its affect on the sports performance spectrum. The International Journal of Sports and Ethics, 1(1), 17.

Yüksel Mf \& Aydos L. (2019). Investigation the effect of footwork on strength and agility parameters of badminton players. Beden Eğitimi Ve Spor Bilim Derg, 13(3). 286-99. 